\section{JOURNAL OF}

French and Francophone Philosophy
REVUE DE LA

philosophie française et de langue française

\title{
Beauvoir's Reading of Biology in The Second Sex
}

\section{David M. Peña-Guzmán}

Journal of French and Francophone Philosophy - Revue de la philosophie française et de langue française, Vol XXIV, No 2 (2016) 259-285.

\author{
Vol XXIV, No 2 (2016) \\ ISSN 1936-6280 (print) \\ ISSN 2155-1162 (online) \\ DOI $10.5195 /$ jffp. 2016.726 \\ www.jffp.org
}

\section{(c) EY-NC-ND}

This work is licensed under a Creative Commons Attribution-Noncommercial-No Derivative Works 3.0 United States License.

\section{ULIS D-Sunt}

This journal is operated by the University Library System of the University of Pittsburgh as part of its D-Scribe Digital Publishing Program, and is co-sponsored by the University of Pittsburgh Press 


\title{
Beauvoir's Reading of Biology in The Second Sex
}

\author{
David M. Peña-Guzmán
}

Johns Hopkins University

\section{The Scientific Face of Beauvoir}

Without a doubt, the single most powerful (and illustrious) element of Simone de Beauvoir's magnum opus, The Second Sex (1949), is her radical declaration that biological processes do not make a "woman." Social relations do. Perhaps more so than any other claim found in any her works, this claim helped Beauvoir bulldoze over the mythos of gender essentialism that has saturated Western philosophy since the days of Socrates, Plato, and Aristotle. Indeed, according to some, this claim turned The Second Sex into the "feminist bible" of the twentieth century. Of course, various other thinkers-living both before and after Beauvoir-have made comparable claims about the relationship between biology and gender, usually from the standpoint of value theory. But what makes Beauvoir's intervention philosophically unique is that her claim about the social construction of sex and gender appears in an specifically "epistemological" and "scientific" context: the first chapter of The Second Sex, "Biological Data" [Les Données de la Biologie], where Beauvoir lays out a meticulous and judicious analysis of the leading biological theories of her time, from evolutionary theory to genetics to physiology. Her groundbreaking assertion that biology is not the overseer of women's lives or the deputy of women's fate is forged in the crucible of what is arguably her most poignant and most direct engagement with the natural sciences.

Unfortunately, while the significance of Beauvoir's thought for social, political, and ethical philosophy has been the subject of extensive discussion in the revelant literature, its import for the philosophy of science has gone virtually unheeded. As of 2016, for instance, there exist no book-length manuscripts on Beauvoir's relationship to the science of biology (or, for that matter, to "science" as such), and one has to probe the ground quite painstakingly just to find the handful of book chapters and journal articles that deal with this aspect of her work. ${ }^{1}$ 
Granted, Beauvoir never wrote a treatise on the logic of scientific inquiry à la Popper, a text on the nature of scientific history à la Kuhn, or an essay on the nature of scientific explanation à la Hempel. So it should not surprise us if her name does not regularly appear in mainstream philosophy of science journals or even, as Anna Mudde points out, in recent debates in the field of feminist science studies. ${ }^{2}$ After all, from a somewhat early age, as we learn in Memoirs of a Dutiful Daughter (1958), Beauvoir was closer to the Balzacs, Prousts, and Collettes of the world than she would ever be to its Darwins, Einsteins, or Freges - her allegiances having been decided as early as her teenage years in favor of three eidolons: "art, philosophy, and literature."3

Still, we know from the primary and secondary literatures that throughout her life Beauvoir viewed science and its problems as objects of intense philosophical curiosity and as topics worthy of serious intellectual engagement. We know from her memoirs that she was reared in the empirical and formal sciences from the time she was a young girl, and that she graduated from the Sorbonne with a teaching certificate in mathematics. ${ }^{4}$ We also know that she appeals to scientific theorems and scientific epistemology at virtually every stage of her career, from her 1924 student essay "Analysis of Claude Bernard's Introduction to the Study of Experimental Medicine" to her 1944 essay "Pyrrhus and Cineas" to her 1945 review of Maurice Merleau-Ponty's Phenomenology of Perception to her subsequent one of Claude Lévi-Strauss's The Elementary Structures of Kinship in 1949.5 Even more notably, we know that the question concerning the status and value of scientific knowledge lies at the heart of her "two extended philosophical treatises"6: The Ethics of Ambiguity and The Second Sex. Why, then, have the ethical and political stakes of the Beauvoirian philosophy overshadowed its scientific and epistemological ones? Why have Beauvoir's numerous remarks about the sciences, both in works leading up to the publication of The Second Sex but also in works following it, been so frequently tossed aside by readers as inconsequential, unmotivated, and even aberrant slip-ups of thought? Why, in other words, do we know so little about her views concerning the nature, structure, and limits of scientific knowledge?

Although it would be hard to pinpoint any one cause responsible for this state of affairs, I suspect that certain habits of philosophical practice that is to say, certain habits of thinking, reading, interpreting, and writing may be to blame, at least in part. It is not uncommon for us (us, academics) to approach our objects of study with certain preconceptions about what those objects are, can be, or should be. Sometimes, of course, these preconceptions are fairly harmless and get confirmed by further study. But sometimes they are not. Sometimes, they are dangerous and self-fulfilling prophecies that prevent us from letting ourselves be surprised by the dynamic, polyphonic, and multidimensional nature of the very objects we 
study. ${ }^{7}$ In the case of Beauvoir, I argue, there are at least two habits that have contributed to the near-total lack of research on her relationship to the sciences in general and biology in particular: first, what Margaret Simons and Hélène Peters call "the popular conception of existentialism as antiscience"8; and second, a certain way of reading The Second Sex that glosses over the details of its critical point of departure. ${ }^{9}$ As "cognitive filters," these habits fill our perceptual field with all sorts of blind spots that shape not only what we see but also what we are in a position to see. They make it easier for us to see in Beauvoir's writitings the traces of some intellectual pedigrees (ethical theory, political philosophy, phenomenology, feminism, existentialism) at the expense of others (epistemology, metaphysics, philosophy of science). At best, they simply mold our understanding of what Barbara Andrew calls Beauvoir's "place in philosophical thought."10 At worst, they render implausible, if not unthinkable, the possibility that Beauvoir's work may reflect a nuanced understanding of the history, philosophy, and epistemology of the life sciences, thereby muting any resonances between her work and that of contemporary philosophers of science and philosophers of biology. ${ }^{11}$

But the fact itself that scientific themes, polemics, and controversies recur in Beauvoir's oeuvre is good evidence that many of the questions typically raised by "orthodox" philosophers of science and biologyincluding questions concerning the anatomy of scientific knowledge, the logic of the empirical method, and the relationship between science and society - lie at the heart of her unique brand of existentialism and perhaps even ground her self-understanding as a social critic. This fact is also an irrefutable sign of the explicitly epistemological ambitions of her feminist project, which the present article intends to bring to the fore.

The article is organized as follows. Firstly, I zoom in on Beauvoir's reading of biology in the first chapter of The Second Sex and illuminate key aspects of her argument by rationally reconstructing it. ${ }^{12}$ The goal of this reconstruction is to clarify Beauvoir's position relative to the science of life and to highlight the places where she merges biology and philosophy in philosophically interesting ways. Secondly, once this reconstructive labor is complete I show that there is a strong affinity between Beauvoir's overall approach to biology and the philosophical method of "immanent critique." In making this affinity explicit, I bring attention to the originality of Beauvoir's thought while contesting the notion that her criticism of biology betrays a pernicious anti-scientism characteristic of existentialist philosophy more generally. Finally, I argue that paying closer attention to the "scientific face" of Beauvoir's philosophy can be advantageous for science, feminism, and existentialism alike. ${ }^{13}$ 


\section{Beauvoir's Reading of Biology: A Four-Point Reconstruction}

Beauvoir considered The Second Sex a "scientific work,"14 and there are two places in it where she makes direct contact with empirical science: chapter I, "Biological Data," where she examines various theories and discoveries from evolutionary theory, genetics, developmental biology, and physiology; and chapter IV, "The Nomads," where she explores anthropological accounts of gender. Both chapters betray a sophisticated understanding of the epistemic authority and social cache of scientific knowledge. They also reflect a distinctive philosophical methodology. Using the chapter on biology as a case study, I show that Beauvoir is not an anti-scientific reactionary who condemns science as a raw expression of economic, political, or social ideology (as some tributaries of orthodox Marxism do). For her, the main problem with various biological accounts of sexual difference is not that they are scientific per se, but rather that they are not scientific enough. Beauvoir, I claim, is a shrewd critic of science who challenges the ideological content of what Imre Lakatos calls "scientific research programs" 15 by holding them accountable to norms of validity and rationality that are not superimposed upon science but extracted from science's own conceptual scaffolding. To substantiate this claim, I offer a rational reconstruction of Beauvoir's argument in "Biological Data" that, despite being chiefly descriptive in nature, should nevertheless help us identify her targets, methods, and objectives and thus better understand how she "works through" (as Freud might say) the philosophical implications of the biology of her time.

In its reconstructed form, her argument in this chapter unfolds in four "moments" or "stages":

- the argument against naturalistic and ontological justifications of sexual differentiation,

- the argument from the concrete reality of sexual differentiation,

- the argument from the philosophy of life, and

- the argument against physiology.

Individually, each of these stages highlights different features of Beauvoir's thinking about the science of life in The Second Sex. Together, they clarify the epistemological stakes of her venture and underscore its proximity to the philosophy of science.

\section{First Stage: The Rejection of the "Natural Law" and "Ontological" Arguments}


Beauvoir's target in "Biological Data" is the thesis of "sexual differentiation" according to which there is an absolute distinction between the sexes that is legislated into existence by the force of nature, being, or existence (and is, therefore, "necessary"). In reality, however, there are two different versions of this thesis:

THE NATURAL LAW VERSION. In this version, sexual differentiation is a universal law of nature that applies without exception to the entire animal kingdom (homo sapiens included). And,

THE ONTOLOGICAL A PRIORI VERSION. Here, sexual differentiation figures not as a law of nature per se, but as a necessary condition for the possibility of human existence. As such, it can be ascertained only vis-à-vis the kind of logico-transcendental investigation characteristic of post-Kantian metaphysical philosophy.

Beauvoir responds to the natural law version with a straightforward empirical refutation. Sexual differentiation cannot be a universal principle of nature because it does not happen universally in the natural world. There are countless species that reproduce asexually, as well as species that have more than two sexes. These prove that sexual differentiation is, at best, a "contingent fact [of nature]" for which no proof can be given. ${ }^{16}$ She also argues that it would be impossible to try to explain the "necessity" of sexual differentiation by reducing it to some metaphysical principle that would "explain" it, such as a natural entelechy or a natural hierarchy. ${ }^{17}$ In contemporary biology, "finalism" and "hierarchism" are obsolete metaphysical concepts. Using either to explain the necessity of sexual differentiation would only violate the most basic norms of empirical procedure and desecrate the spirit of rational investigation upon which the modern scientific enterprise is based.

Against a long history of metaphysics that extends from Plato to Hegel and that regards sexual differentiation as somehow written into the very logic of being or existence, Beauvoir also argues that there can be no "ontological proof" of sexual differentiation as that there are very few ontological truths that follow from the concept of "being" or "existence," and sexual differentiation is not one of them. Drawing upon MerleauPonty's work in The Phenomenology of Perception, 18 she notes that only two ontological truths follow from the fact of human existence: first that $I$ necessarily have a body that is both subject and object of perception; and second that my body is structurally underdetermined by the requirements of perception, meaning that my body "need not possess this or that structure" in order for it to fulfill its function as the epicenter of perception. ${ }^{19}$ Nothing in the logic of being or in that of existence demands that my body be sexed in any specific way or even that it be sexed at all.

Now, just as we cannot defend the natural law version from the empirical refutation by reducing sexual differentiation to some more 
fundamental metaphysical principle (be it an entelechy or a hierarchy), we cannot save the ontological version by reducing sexual differentiation to some other, primitive, ontological structure that explains it. Consider the following hypothetical ontological proof, which Beauvoir introduces and rejects in "Biological Data," and which I here present in summary form to clarify this point.

HYPOTHETICAL PROOF: SEX DIFFERENTIATION AS THE NECESSARY, MATERIAL CONDITION FOR THE POSSIBILITY OF HUMAN TEMPORALITY.

In Being and Nothingness (1943), in the midst of a polemic against Heidegger's philosophy of finitude, Sartre alleges that "a temporally limitless existence is conceivable." For Sartre, we can conceive of a kind of existence without finitude, which Heidegger's ontological project ardently rejects. What this limitless existence is or looks like, however, Sartre does not say. But in The Second Sex Beauvoir claims that someone could use this Sartrean insight to construct an "ontological proof" for the theorem of sexual differentiation. This proof would go like this: first, the only "temporal infinity" we can truly conceive in relation to humans is the infinite existence of the human species (since individual humans are necessarily mortal); second, the infinity of the species would necessarily require "the perpetuation of the species" (since without perpetuation, the species could not exist in perpetuity); perpetuation in the human case is materially achieved vis-à-vis reproduction, which in turn requires the existence of two sexes; therefore, sexual differentiation is a necessary part of the ontological structure of human temporality. ${ }^{20}$

No philosopher (at least no philosopher I know of) has defended this particular line of reasoning, and Beauvoir does not imply otherwise. But she uses this scenario to show that even this hypothetical, Sartrean "proof" of sexual differentiation would not work. The most this line of reasoning can prove is that the perpetuation of the species is an essential part "of the concrete definition of existence." But what it cannot prove is precisely what it aims to prove-namely, that this perpetuation must be achieved by means of sexual reproduction. Beauvoir grants that perpetuation might entail reproduction. But reproduction, she says, "does not entail sexual differentiation." Hence, just as Sartre can imagine a "temporally limitless existence" in Being and Nothingness so, too, we can imagine a temporally limitless existence that does not involve of sexual differentiation. All we have to do is "imagine a parthenogenetic [...] society," 21 i.e., a society that reproduces but not by sexual means. ${ }^{22}$

When it comes to sexual differentiation, Beauvoir concludes, "we find ourselves before a fact that has neither ontological nor empirical basis and whose impact cannot a priori be understood." 23 As a fact of nature, sexual differentiation is both "contingent" and "irreducible." If we want to clarify 
its significance, we must leave behind the higher flights of nomology, metaphysics, and ontology and turn instead to this phenomenon's "concrete reality." 24 This ushers in the second phase of Beauvoir's argument.

\section{Second Stage: The Argument from the Concrete Reality of Sexual Differentiation}

In the second stage of her argument, Beauvoir takes up the suggestion that only an inquiry into the concrete reality of sexual differentiation should direct our biological and philosophical theories of sex and sexuality, and she argues that if we look at this reality with a sober and analytical eye-which is to say, without the distorting effects of patriarchal expectations - we come to realize that this natural fact does not mean what, often, professional biologists think it means. That at some point in its evolutionary history a species split into two sexes, for example, means neither that one sex outvies the other nor that we can make any inferences about the "sexed status" of any particular member of the species. From the fact that sexual differentiation exists, relatively little follows.

For example, sexual differentiation-understood as "gamete specification," i.e., as the evolution of two distinct gametes whose partnership is necessary to achieve the reproductive function-entails no value- or activity-differentials between the gametes since relative to the act of reproduction itself "neither gamete takes precedence [over the other]." 25 Unfortunately, biologists often describe reproduction and construct biological hypotheses in ways that imply the supremacy of one gamete. The reason is that biology has for a long time been under the sway of an ideological prejudice whose roots can be traced all the way back to Aristotle's form/matter distinction: the patriarchal assumption that the maternal element is a fundamentally passive and almost immobile container (the ovum as "a nocturnal heaviness"), while the paternal element is a fundamentally active principle that initiates, forms, and achieves (the semen as an agent that "embodies the impatience and worry of existence [itself]"). ${ }^{26}$ This assumption often sneaks into the research process as a hidden premise and affords a false sense of validity to judgments that assume or defend differentials in value or potentiality between the gametes (and, by extension, between the sexes). ${ }^{27}$

But this prejudice, Beauvoir says, is empirically false. She writes:

It is false to claim that the egg voraciously appropriates the female cell's reserves because in the act that merges them, their individuality disappears [...] besides the details of the psychochemical interactions leading to fertilization are not known. It is possible, however, to come away with a valuable indication of this meeting. There are two movements that come together in life, 
and life maintains itself only by surpassing itself [...] The conclusion is thus that fundamentally the role of the two gametes is identical; together they create a living being in which both of them lose and surpass themselves. ${ }^{28}$

With this claim, Beauvoir problematizes both the common equivocation of maleness with activity, and the assumption that it is always the passive female that carries the (almost moralistic) onus of ensuring the reproduction of the species. All we know with certaining about the logic of reproduction, she says, is that there are two movements that together "create a living being": the movement of the ovum and the movement of the sperm. Anything beyond that is either an ideological projection rooted in patriarchal principles or a simple confusion about the present state of biological knowledge.

In addition to telling us nothing about the axiological or even functional importance of each gamete, sex differentiation tells us nothing about the features of particular organisms because gamete specification does not necessarily entail organismic specification along gametic lines. Even if we know that the germline of a species has split in two over the course of phyletic time, we still cannot infer anything from this about any one particular member of this species. We cannot predict, for instance, which members will belong to which gametic groups. We cannot even infer that all members must by necessity belong to one and only one of the two groups. After all, even in species marked by sex differentiation in the form of gametic specification there are particular organisms that flout binarism. Some animals, such as Bonellia viridis (the green spoonworm), begin their life cycle as asexual only to later develop a determinate sexed identity, meaning that they effectively belong to multiple sex-identities over the course of their life. Meanwhile, others, such as some species of toads, are endowed with what Beauvoir calls "sexual bipotentiality," meaning that they "possess characteristics of the complementary sex." 29 "Even in species where sexual division is the most clear cut," Beauvoir says with homo sapiens in mind, "there are individuals that are male and female simultaneously." 30 Her analysis of hermaphroditism appears precisely at this junction of her work. ${ }^{31}$

The gap between gametic and organismic specification reveals the plasticity of the sex categories, which is also confirmed by laboratory experiments on grafting and castration that demonstrate that the process of sex determination can be experimentally and environmentally derailed. This gap also reminds us that we cannot jump from explanations couched in terms of gonad-properties to explanations couched in terms organismproperties (as many professional biologists do) because the relation between the two is highly variable and complex, and because these two sets of properties may not map onto one another in a neat, one-to-one fashion. ${ }^{32}$ From a strictly evolutionary perspective, as Sigmund Freud claims in Beyond 
the Pleasure Principle (1920), the germ-lines "separate themselves from the organism as a whole [and] acquire a separate existence." 33

\section{Third Stage: The Argument from the Philosophy of Life}

At this point in her argument, Beauvoir leaves behind what up until now has been an almost exclusively negative outlook (her criticism of sexual binarism) in order to take up the more positive task of elaborating a theory or philosophy of life. This movement, which brings Beauvoir's prose surprisingly close to eighteenth century natural history and nineteenth century Lebensphilosophie, is a crucial piece of the puzzle of her engagement with biology. In fact, this movement toward a grandiose (almost catholic) philosophy of life plays a central role in her demand that existential phenomenology take more seriously women's experience of embodiment, which is shaped in important ways by women's position (as Beauvoir sees it) as the least individualized and least free members of the most individualized and most free species. ${ }^{34}$

The animal kingdom, Beauvoir says, is not an amorphous collection of organisms of varying morphological, genetic, and phenotypic forms. On the contrary, it is a taxonomic order with a certain "logic" that, when viewed as a whole, forms an internally coherent totality. Because of this logic, the kingdom animalia is structured in such a way that each animal, from the termite to the human, occupies a precise and fixed place in it. Now, typical post-Darwinian classifications of animals arrange living organisms according to a specific "logic": the logic of common descent. But Beauvoir's classification breaks this mold. In a radical departure from classical cladistics, she classifies animals according to an entirely different "logic" rooted in three organizing principles:

1. THE PRINCIPLE OF MOUNTING INDIVIDUALITY. This principle holds that as we move from the "lower" to the "higher" species in the animal kingdom, the individuality of the members of those species (understood as freedom from the necessitation of nature) intensifies. The animal kingdom, therefore, can be thought of as a gradient of mounting individuality. "One of the most noteworthy features when surveying the steps of the animal ladder is that, from bottom to top, life becomes more individual; at the bottom it concentrates on the maintenance of the species, and at the top it puts its energies into single individuals." 35

2. THE PRINCIPLE OF THE SEXUAL MONOPOLIZATION OF INDIVIDUALITY IN "HIGHER" ANIMALS. This principle holds that although individuality intensifies as we move up the chain of animal being, individuality also gets increasingly monopolized by, or centralized in, the male sex of each species. What intensifies in the 
female sex of the higher species is specific subordination, i.e., the domination of the individual female by the species. "Woman, the most individualized of females, is also the most fragile, the one who experiences her destiny most dramatically and who distinguishes herself the most significantly from the male." 36

3. THE PRINCIPLE OF SEX FUNCTIONALISM. This is the twofold idea that (a) species are maintained by the dialectical interplay of two metaphysical forces (continuation and rupture) ${ }^{37}$ and (b) each sex within a sexually differentiated species represents one, and only one, of these forces. For Beauvoir, the female sex carries the onus of continuation (through fertility, pregnancy, and reproduction), while the male sex carries the privilege of rupture (through the exercise of freedom and autonomy).

The philosophy of life generated by these principles is, frankly, the least persuasive and most confusing aspect of Beauvoir's reading of biology. It is unpersuasive because it grows from uncritical interpretations of gender roles in the animal kingdom, with Beauvoir at times describing the behaviors of male nonhuman animals (such as beetles) as "assertive" and "gratuitous" and those of their female counterparts as "sad" and "oppressed." It is confusing because it recapitulates outmoded scientific concepts and distinctions (natural order, "high" vs. "low" animals, etc.) that not only seem incompatible with post-nineteenth century biology, but also seem to clash with Beauvoir's own philosophy in both letter and spirit. ${ }^{38}$ Even so, Beauvoir leans on this view of life to make a critical observation about the interface between nature, existence, and experience-namely, that the operations of existence will always exceed the operations of nature and cannot be contained by them. Echoing Hume's famous dictum that no ought can ever be derived from an is ("the naturalistic fallacy"), she maintains that empirico-natural facts about women's biology cannot ground or justify women's social positions and situations.

With this observation, Beauvoir makes a solid case for existential phenomenology's independence from empiricism. And her strategy is relatively straightforward: (1) she presents a comprehensive theory of nature, (2) she grants that this theory allows for natural differences between the sexes, and then (3) she clarifies that even if (1) and (2) hold true, they have zero consequences for the theory of existence. Biological facts may "enable us to understand woman," but they cannot "form a fixed destiny for her." 39 As Moira Gatens has put it, "[biology] can play a crucial role in deciding one's health, one's sex, one's strength, even one's life span. But it does not, and according to Beauvoir cannot, determine how one interprets these factors or how they are lived by the free subject." 40 Consequently, any biological program that presents "facts" as nature's Bauplan for the elaboration of subjectivity will inevitably surpass its own limits and get dangerously close to becoming an ideology. 
With this observation, moreover, Beauvoir brings questions of female embodiment to the core of existentialist philosophy and cautions against the masculinist bias of classical phenomenology. ${ }^{41}$ Since of all living animals, in her view, women are the ones that suffer most on account of being simultaneously most individualized (qua human) yet also most alienated from their individuality (qua female), their relationship to their body is not the same as that of their male counterparts. ${ }^{42}$ Nature makes a phylogenetic, ontogenetic, and developmental "claim" on women's bodies that burdens them with the continuation of the species, a claim is often expressed via biological processes (the development of breasts during puberty, the onset of menstruation, the possibility of pregnancy and lactation, the inevitability of menopause) that trap women in a plane of pure immanence.

Surely, these processes are natural in the sense that they are naturally occurring. But, in Beauvoir's view, women systematically experience them not as organic components of the musical flow of lived experience, but as acute "crises" that instigate a full-blown war between women and their biology. Whereas men experience their biological body as an axis of possibility and as the cradle of all their existential projects, women experience theirs as the footing of their subjection to the species, as that which forestalls their ability to engage in the most important project of all: transcendence. Women experience their body as the site of a punishing immanence, as "an alienated opaque thing" that suffocates them and restricts their ability to assert themselves as free and autonomous agents. "Woman is her body as man is his, but her body is something other than her," she says.43 If existentialism and phenomenology want to matter to women, Beauvoir seems to be implying, they must take notice of the unique logic their embodiment and the biological conundrum that frames it. ${ }^{44}$

\section{Fourth Stage: The Argument Against Physiology}

While the first three stages of Beauvoir's argument deal primarily with evolutionary theory, the fourth and final stage torques the focus toward physiology. Here, Beauvoir puts under the microscope the idea "that physiology alone provides answers to [the following] questions: Does individual success have the same chances in the two sexes? Which of the two in the species plays the greater role?" Physiological research may teach us a great deal about the normal functioning of men's and women's bodies, but it cannot tell us whether a specific sex is "more successful" or "greater" - or some other comparative - than its counterpart because the meaning of these very concepts ("success" and "significance") is not exclusively empirical. It is also social. And, as social, it is both time- and context-sensitive.

Beauvoir elaborates this claim through an essentially anthropocentric and humanist gesture. She argues that there is a radical break between human and nonhuman animals. Humans have the ability to engage in acts 
of what in Being and Nothingness Sartre calls "negation" or "transcendence" through which we lift ourselves above the order of natural necessity. By contrast, nonhuman animals are incapable of this critical function and so remain confined to the sphere of immanence that effectively demarcates empirical science's domain. Thus, what counts as "success" for nonhuman animals falls within the ambit of the empirical (species-typical functioning, above-average behavioral outputs). Meanwhile, what counts as "success" for humans is correlated with non-empirical acts of transcendence that, precisely as non-empirical, escape science's conceptual reach. For the human, what counts as a "task" and what counts as "success" in relation to it is always, much like humanity itself, "in the making." 45

Imagine we want to study whether "the mare is as quick as the stallion, [or whether] male chimpanzees do as well on intelligence tests as their female counterparts." 46 To find an answer, all we need to do to is phone the expert equestrian or the professional primatologist and request the latest empirical data on the subject. Surely, ethological observation and behavioral experiments can tell us whether on average stallions outrun mares in speed competitions and whether also on average male chimps solve mazes and puzzles faster than their female counterparts - the question of "success" being, in both cases, a purely empirical one since nonhuman animals (male or female) can only embark on those projects that are rendered possible by their natural bodies and natural functions. ${ }^{47}$ By contrast, human animals engage in acts of transcendence by which we transcend our very animality. Hence, an empirical science like physiology may effectively determine whether a specific sex is "stronger" or "faster" in a nonhuman species, but it cannot make the same determination relative to the human case. From this Beauvoir concludes that physiological knowledge "doesn't apply to women and other [non-human] females in the same way."

Beauvoir also rejects physiological justifications of masculine domination on the grounds that they tend to presuppose a questionable principle of "psychophysiological parallelism." They assume, in simple terms, that the quantitative study of normal organic functions can somehow define an organism's psychological capacities and, by extension, existential possibilities; that psychological and existential functions (intelligence, behavior, success, etc.) can be somehow reduced to quantitative metrics (heart rate, brain weight, body mass, etc.). Yet, there are two downsides to this reductionist attitude. One is that quantitative measurements are not always absolute and unassailable. In fact, they can be misleading depending on how scientists approach the object being measured and what variables they include in, or exclude from, the act of measurement itself. Another is that even when quantitative measurements are conducted in line with scientific procedure and can properly be termed "objective" -i.e., even when scientists control for variables, take into account margins of error, and consider the role that the act of measurement itself plays in "disclosing" the 
object - they still cannot be said to exhaust the functional potential of their object. It is always in principle possible that an object can do more than what a sequence of measurements reveal and that its functioning in the future may differ from its functioning in the past.

Consider the human brain. Sometimes, physiologists study the human brain, including its structure, functioning, and composition. And sometimes, they do so with the explicit intent of studying gendered differences in cognition, including cognitive ability, aptitude, and adaptability. Historically, research into the so-called "gendered brain" has been used by a wide range of actors and stakeholders, from scientists to policymakers, to reinforce women's oppression and vindicate their collective status as second-class citizens. 48 If it can be empirically proven that women's brains are on average "smaller" or "weaker" than men's, or so the argument goes, then we have a non-arbitrary basis for characterizing women's position of servitude as "natural" and potentially "obligatory." In The Second Sex, however, Beauvoir works against the naturalization of patriarchy by way of physiology ${ }^{49}$ by observing that the distance between the facts of physiology to the norms of patriarchy is larger than those who want to close it in one leap imagine. In fact, there are various obstacles that prevent us from making this leap at all.

One of these obstacles is the fact that the "measurements" made by scientists are not absolute and enduring truths. They are constructions whose logic of generation can be subjected to scrutiny and whose meaning depends by and large on the many background assumptions that frame them. For example, when physiologists measure "brain size" in order to determine whether men and women think differently, a lot hangs on how the concept of "size" is interpreted and what variables are used to measure it. By "size," do we mean length, circumference, volume, or weight? And once we settle on one of these variables (or on a function involving multiple of them), the question remains of how that variable is to be interpreted. Suppose we decide to study brain size vis-à-vis brain weight. We still have to determine what metric of "weight" will be used. Will we use "absolute weight" or "relative weight"? And, if the latter, weight relative to what exactly? Relative to body weight, intracranial volume, or something else? These questions matter because the results of a scientific investigation - the conclusion that can then be mobilized by various stakeholders as a premise in the defense of women's disenfranchisement-depend on the answers we give to them. The parameters of the act measurement shape the act itself and impact its results. ${ }^{50}$

Another obstacle has to do with the interpretation of the "findings" of physiological studies. Beauvoir says that even when the professional physiologist interested in the interface between brain and gender succeeds at laying out a vast number of data points and finding statistically significant patterns among them, she still cannot make any legitimate inferences about 
something like "intelligence" because the relationship between physiological variables (e.g. brain size) and psychological functions (e.g. intelligence) is not easy to determine. In fact, "no relation has been established between brain weight and the development of intelligence." To reduce the psychological to the physiological in this manner is farcical, as farcical as attempting to give "a psychic interpretation of the chemical formulas defining male and female hormones."51 Just as a philosopher cannot successfully derive an ought from an is, a physiologist cannot successfully reduce a quality to a quantity. ${ }^{2}$ Beauvoir concludes, and with this she brings "Biological Data" to a close, that physiologists are incapable of claiming for themselves the objects that, properly speaking, belong either to psychologists (intelligence, behavior, mental processes) or to philosophers (existence, experience, life). Why? Because they (the physiologists, that is) cannot give a satisfactory account of the relationship between the physiological and the psychological that would permit them to reduce the second to the first. "We categorically reject," she says, "the idea of a psychophysiological parallelism; the bases of this doctrine [are] philosophically and scientifically ruined, [even if] it still haunts a number of minds." 53

\section{The Four Stages Considered as "Immanent Critique"}

If we step back from the different stages of Beauvoir's commanding reading of biology in The Second Sex and focus instead on the trajectory of her argument on the whole, we discover important parallels between her approach and the method of immanent critique typically associated with the Frankfurt school of critical theory.

In general terms, "immanent critique" refers to a method of critiquing an object-be it a theory, a worldview, a situation, a practice, or an institution - in light of the object's own claim to normativity, which is to say, in light of the aspirations, values, and commitments of the object itself. With academic texts, for example, immanent critique discovers and reveals what the German theorist Bernhard Forchtner calls "text-internal contradictions," 54 which are tensions internal to the work itself that hint at a possible asymmetry between, on the one hand, what the text claims to do (its self-understanding) and, on the other, what it actually does (its material reality). Of course, immanent critique can never be the simple, mechanical application of a master blueprint of "critique." It must always take its lead and energy from the specificity and uniqueness of the object at hand, independently of whether this object is a text (a book, a declaration, a document, a manifesto, etc.) or something else (a social custom, an economic process, a political infrastructure, a legal practice, etc.). In all cases, however, the aim of immanent critique is to critically evaluate objects on their own 
terms by determining whether they measure up to their own norms or whether they, in some sense, fall short of them. ${ }^{55}$

In "Biological Data," Beauvoir employs five "theoretical tactics" that bring into heightened relief the affinity between her approach to thinking about science and the method of immanent critique. These five tactics enable her to interrogate specific biological theories as to whether or not they are in good standing relative to the norms, requirements, and strictures of biology itself. They allow her to "enter" her object (biology) so as to evaluate it on its own normative terms.

First, Beauvoir exposes gaps in the fabric of biological knowledge that biological experts tend to gloss over or repress. Repeatedly, Beauvoir draws our attention to scientific inferences that present themselves as logically irrefutable or empirically unassailable while relying on premises that have not met the right standards of empirical or evidentiary support. One example is the physiological theory of gendered cognition described above. This theory claims to capture the difference between "male" and "female" intelligence by studying differences in brain size. Yet, this theory presupposes a direct and probably also causal link between a physiological variable and a psychological/existential function. But, again, we have no reason to accept this presupposition as true given that "no relation has been established between weight and the development of intelligence." 56 What we must take notice of here is Beauvoir's real target. Her first and most significant objection to the physiological theory of gendered cognition is neither that this theory typecasts women based on their biology and replicates gender stereotypes nor that it clashes with Beauvoir's own social, political, and philosophical beliefs. Sure this typecasting and this clash are problems, but they come later. The first and main problem with the physiological theory of gendered intelligence is more basic but also, for that reason, more devastating: the evidence does not bear it out such that it fails to be properly "scientific." (The same is true of the biological theory that reproduction is the "penetration" of a passive ovum by an active sperm. $)^{57}$

Second, Beauvoir highlights key concepts that appear in biological discourse but that, not being themselves strictly speaking biological or even scientific, have to power to lead biology astray (i.e., beyond its proper domain) by lading it with all sorts of values. Every once in a while, extra-scientific concepts infiltrate scientific language and percolate the scientific literature. And while in many cases little comes of these concepts (especially when they are only incidental aids to scientific explanation and scientific writing), in some instances they have the potential to wreck epistemic havoc in science, especially if they carry significant extra-scientific baggage. For example, many physiological controversies in the late-nineteenth and early-twentieth centuries revolved around questions of gendered and racial superiority. Is there a race that is "the strongest"? Is there a sex that is "the weakest"? To be sure, part of the problem with these debates is that they were part and parcel of a larger 
culture of male and while privilege. Their motivation from the start was to answer a question that only this larger culture would have a vested an interest in posing. But part of the problem is also that they employed concepts that are not, technically speaking, scientific and whose meaning is neither clear nor precise (such as the concepts of "strength" and "weakness"). What can these concepts possibly mean in a biological context? Chances are that concepts like these enter science, in this case physiology, by way of common sense and everyday experience. But precisely because of their extra-scientific origins, science must either avoid using altogether or give a clear defense for their use and a sharp account of their scientific meaning. Beauvoir's point, of course, is not that these concepts can never be subjected to systematical and rigorous investigation. It is simply that the sort of inquiry needed for their analysis far exceeds the job description of a professional biologist. ${ }^{58}$

Third, Beauvoir reveals cases of "explanatory cherry-picking" on the part of biological theories. The main function of scientific theories is to explain phenomena. But because no theory to date has succeeded at unifying all observed phenomena under one roof, each theory must content itself with explaining a particular slice of the world. Unfortunately, some theories claim for themselves more explanatory power than they really possess and, as it were, bite more of the empirical world than they can chew. When this happens, these theories (or, rather, their defenders) are forced to "cherrypick" the phenomena they explain and sometimes to even disregard evidence that has the power to falsify them. Throughout "Biological Data," Beauvoir flags instances of this kind of cherry-picking and scorns biological theories for artificially inflating the scope of their explanatory reach. A case in point is the biological thesis that there are only two sexes in nature, which is the subject of most of chapter one. This theory may be a helpful heuristic for thinking about many species in the animal kingdom, but all too often it overreaches and presents itself as true without qualification (i.e., as applicable to the entire animal kingdom in an absolute fashion). Beauvoir qualifies this theory precisely by reminding us that the examples rallied by its supporters are cherry-picked and that there is a myriad of cases that contravene it, such as the existence of hermaphroditic individuals as well as the (now experimentally verified) variability of the process of sexdetermination itself. 59

Fourth, Beauvoir shows that scientific conclusions can be refuted from within the same standpoint that produces by tweaking the parameters of investigation. In scientific contexts, investigative outcomes depend not only on input but also on the operationalization parameters that turn input into output. Thus, it is very likely that one will obtain different results if one tweaks these parameters, say, by changing the variables under investigation or altering how these variables are measured, analyzed, and interpreted. Consider the physiological theory of intelligence that Beauvoir takes up at the end of the 
chapter which takes intelligence to be a function of brain size. Even if we allow that intelligence is the sort of thing that can be quantified (which is contentious), there is still the question of which variable or variables will be used to measure it-brain weight, brain volume, brain diameter, or some other metric. Now, let us assume we settle on brain weight. We still have to specify what we mean by "weight." If we define weight as "absolute average weight," women are proven to be on average less intelligent than men. But if define it as "relative weight" (i.e., weight relative to body size), the results flip around and women turn out to be on average smarter than men. ${ }^{60}$ Furthermore, if we define it by yet another metric (e.g. by dividing average weight by .56 of body weight), we get a new and different result. In this last case, "equality is the result." 61 This suggests that scientific results are products of investigative decisions that, even while occurring under settings of feedback-controlled action, involve and reflect a good deal of human judgment, including judgments about what gets studied, how it gets studied, and why it gets studied in the first place.

Fifth and finally, Beauvoir spots theories that lend themselves to dubious social ends and that continue to have traction in scientific debates solely on account of their social utility (i.e., after they have lost their empirical content or predictive muscle). Sometimes experts accept scientific theories that merely happen to go hand-in-glove with a dominant ideology - racism, sexism, heterosexism, and ableism. In these cases, it may be possible to distinguish between the epistemic legitimacy of the theories in question and their function as sources of social legitimation (although the distinction itself probably should be questioned). But sometimes experts accept scientific theories because they go hand-in-glove with a given ideology and because they aid and abet in the rationalization of social being. In these cases, it is impossible to differentiate between a theory's claim to "legitimacy" and its role as an agent of "legitimation" since the only legitimacy such a theory enjoys is the ersatz legitimacy afforded to it by its usefulness as an instrument of social legitimation. Beauvoir gives two examples of scientific theories that fall under this second category and are accepted in spite of there being no real evidence for them (or for choosing them over competing theories) and, in one case, in spite of there being good evidence against them. One is the theory that portrays pregnancy as a "harmonious relationship" between mother and fetus. This theory, Beauvoir says, is "obviously useful socially" but lacks the rigor, precision, and empirical adequacy of true science. ${ }^{62}$ The other theory is the theory of sex differentiation espoused by Alfred Fouillée in his 1895 book Tempérament et caractère selon les individus, les sexes et les races, where Fouillée tries to deduce the essence of woman from the nature of the ovum and the essence of man from that of sperm. This theory, too, possesses vast reserves of social, political, and psychological cachet. Yet, it suffers from a near total lack of scientific substance as it frequently relies on "dubious analogies" and "pseudo-thinking [pseudo-pensées]." The first of these theories is accepted even though there is no good evidence that 
supports. The second is accepted even though there is good evidence that falsifies it. 63

These five tactics emphasize the varied ways Beauvoir's thinking links up with historical and contemporary debates in the philosophy of science, including debates concerning the value-ladenness of science, the demarcation between science and pseudo-science, and the influence of sociopolitical determinants on the cognitive process. They also demonstrate the proximity between Beauvoir's approach to the science of biology and the method of immanent critique. In my reading, it is theoretically significant that Beauvoir never rejects biology as an anti-feminist paradigm or equates it with a political ideology. If anything, she repeatedly professes her faith in it as an epistemic enterprise. Biology, she says, gives us real knowledge about the world, including about the history of the species, the processes that govern reproduction, development, and growth, and the myriad material, organic, and natural determinants that act upon men and women over the course of their natural lives. "Biological data are of extreme importance; they play an all important role and are an essential element of women's situation." 64 They "cannot be denied." 65 And even if the meaning of biological facts is not for biologists alone to determine, biology itself does not lose any of its epistemic status or prestige on that account. It remains a legitimate epistemic venture that no self-respecting philosophy can offhandedly brush aside. Beauvoir, therefore, accepts the norms that according to the scientific community make for good inductive practice (i.e., the primacy of observation, the requirement of internal consistency, and the importance of empirical adequacy). She simply uses these norms to evaluate the observational and theoretical claims of the biology of her time. 66 Thus, while her tone in this chapter is decidedly "critical," she is not "critiquing" biology in the sense of de-legitimizing it. She is "critiquing" it in the sense of holding it accountable to itself, which is to say, in the sense of immanent critique. The conclusion I draw from this is that the endgame of The Second Sex is not a ruthless "unmasking" of biology as ideology, but a critical and clever engagement with biological reason that acknowledges the value of biological knowledge while recognizing that this knowledge has the potential to become ideological in particular instances.

If there is anything this work successfully "unmasks," it is what I call biology's hubristic impulse (from the Greek ü $\beta \rho \imath S$, meaning arrogance or excessive pride), which is its tendency to become overly confident of itself always, of course, to its own ruin. By the end of the opening chapter on biology, Beauvoir's message to biology is really quite simple: "do not stray too far from your island of true (i.e. corroborated) knowledge for otherwise you risk becoming fallacious and ideological." For her, scientific programs falls from epistemic grace when they refuse to accept their limits, gaps, and ambiguities; when they become so attached to specific interpretations of phenomena that they cannot change, evolve, or adapt in light of new 
evidence, new circumstances, or new situations; when they apply concepts outside their proper domain or claims for themselves concepts that their own formal and empirical methods are unable to accommodate. A scientific domain becomes ideological when, in a flagrant display of hubristic arrogance, it fails to abide by its own principles and rules. In these cases, a domain that might otherwise have a good claim to epistemic legitimacy becomes epistemologically dubious. It ceases living in the element of truth and authenticity, and slips into its very own form of epistemic "bad faith."

\section{Uncharted Depths: Science Beyond “Biological Data” and The Second Sex}

By hanging a lantern on Beauvoir's multi-layered reading of biology in The Second Sex, I have sought to bring to light the scientific face of her philosophy and accentuate what Moira Gatens calls "the continuing relevance of [her] philosophy for present-day readers," 67 especially for those interested in science, existentialism, and feminism. ${ }^{68}$ At the same time, I have sought to use Beauvoir's engagement with biology to deflate the popular conception that existentialist philosophy is by design "anti-science," which has become popular in some philosophical circles.69 This conception is dangerous because it hampers our critical imagination and prevents us from recognizing the profound historical and conceptual links that exist (or could exist) between science and existentialism., and because it keeps us from building intellectual coalitions that deepen (or could deepen) our understanding of both the existential dimensions of scientific practice and the scientific dimensions of human existence. It is also dangerous because it is a self-fulfilling prophecy. It contributes to the scarcity of research by which, in turn, it justifies itself. If there are no links between existentialism and science, there must be no need to do research on the subject. And if there is no research, it must be because there is no link. My analysis,, however, suggests that Beauvoir's chapter on "Biological Data" ruptures this circular reasoning by giving us a concrete snapshot of what a mutually enriching dialogue between existentialism and science looks like.

But here a caveat must be introduced: my reading is not without its flaws and limitations. My reading, for instance, focuses entirely on Beauvoir's reading of biology, leaving her readings of experimental medicine, ${ }^{70}$ sociology, ${ }^{71}$ and anthropology ${ }^{72}$ essentially untouched. Of course, the decision to privilege biology is not entirely arbitrary since the chapter on biology is the place where Beauvoir's scientific and epistemological interests assert themselves most uncompromisingly and with indisputable force. Still, this decision is a decision that, like the decisions scientists make on a daily basis, involves value-laden judgments and the possibility of human error. My reading, furthermore, is limited to The Second Sex. A more comprehensive account of Beauvoir's relationship to 
positive science would have to go beyond this text. Such an account would have to delve into Beauvoir's early education and study in unremitting fashion the many scientific texts, figures, and problems that captured her imagination as a student. It would have to trace the evolution of her thinking about science over the course of her entire career from Memoirs of a Dutiful Daughter (1958) to All Said and Done (1972), passing through The Prime of Life (1960) and The Force of Circumstance (1963) along the way. Such an account would also have to explore how her interests in science and epistemology came to manifest themselves both throughout The Second Sex (not just in its opening chapter) and in works other than The Second Sex (such as The Ethics of Ambiguity [1947] and her many works of literature). Finally, a truly comprehensive reading would need to tackle the enormously complex issue of "intellectual influence" and tease apart Beauvoir's relationship to scientific thinkers as varied as Leon Brunschvicg 73 Gaston Bachelard, ${ }^{74}$ Henri Bergson, ${ }^{75}$ and Jean Piaget, ${ }^{76}$ among others. But since reaching this level of completeness is beyond the scope of the present piece, I have no choice but to leave the task of exploring these uncharted depths of the Beauvoirian undertaking to other scholars.

But just as this reading is not without its shortcomings, it is also not without its returns. To start with, my reading helps us recognize that there are substantial epistemological questions at stake in Beauvoir's work and that there are parallels to be drawn between her philosophy and various "schools of thought" with which it her work not typically associated, especially the philosophy of science. More importantly perhaps, my reading also helps us overcome one of the central problems in the Beauvoir studies literature, which is the problem of how to read The Second Sex as a whole in light of it apparent internal disunion.

Allow me to explain this point in more detail. The Second Sex is divided into two volumes: volume I "Facts and Myths" and volume II "Lived Experience." Volume I deals with various theoretical discourses (such as biology, psychoanalysis, Marxism, and history) using a method of critical analysis. Meanwhile, volume II deals with women's experiences of alienation over the course of their lives (from childhood to puberty to sexual initiation and beyond) using a method of radical phenomenological description. It has been claimed that since these volumes have different objects and methods, there is a tension between them that splits The Second Sex in half. How do these volumes relate to one another? Why do they cohabitate under one roof? Typically, this question has been resolved by presenting the objects discussed in volume I (including biology) as "part[s] of the theoretical framework of patriarchy," i.e., as social forces that contribute to the alienation of women discussed in volume II. ${ }^{77}$ On this view, however, the only link between the objects of volume I and the object of volume II is that the former shape the latter by constructing ideological edifices that have an alienating effect on women's experience of the world. ${ }^{78}$ 
I find this view deficient, or at least incomplete. Volume I is not only about scientific myths. As its own title indicates, it is also about facts. It is about facts that, in Beauvoir's own words, "cannot be denied." Hence, it is not only the myths perpetrated by biology (e.g., the myth of pregnancy as a perfect harmony between mother and fetus) but also the facts discovered by it (including genetic, chemical, and evolutionary facts) that shape women's experience of the world. This is why, for instance, Beauvoir observes in the final pages of "Biological Data" that as long as classical phenomenology remains ignorant of the facts of women's biology, it cannot hope to understand the logic of women's embodiment. This is also why the events that appear in volume I as "biological crises" (the development of the breasts during puberty, menstruation, pregnancy, menopause) re-appear in volume II as "moments of existential alienation" - because, under Beauvoir's philosophy, women's experience depends not only on the social dimensions in which biological facts acquire meaning but also on the biological facts themselves. The content and concerns of volume I, therefore, are not extrinsic to the content and concerns of volume II but integral to them. And this is precisely what my reading enables us to see-namely, that a phenomenology of the second sex (i.e. volume I), insofar as it is the phenomenology of a sex with a unique biology, has no choice but to commence from the data of biology, which is to say, from the biology of the second sex.

${ }^{1}$ Abigail Klassen compares Beauvoir's philosophical methodology in The Ethics of Ambiguity (1947) to the skeptical method charted by Francis Bacon in The New Organon (1620), arguing for a "compatibilist" reading of Beauvoir's ethics and the ethos of positive science; see Abigail Klassen, "Beauvoir, the Scandal of Science, and Skepticism as Method," Hypatia 28.4 (2013): 835-851. Toril Moi contends that Beauvoir manages to "swerve away" from Sartre's negative ontology by mixing the epistemology of biology with a "materialist" theory of women's existence; see Toril Moi, "Existentialism and Feminism: The Rhetoric of Biology in The Second Sex," Oxford Literary Review 8.1 (1986): 88-95. Linda Zerilli presents a valuable analysis of women's species-being, biology, reproduction, and the symbolic by comparing Beauvoir's materialism to Kristeva's; see Linda Zerilli, "A Process Without a Subject: Simone de Beauvoir and Julia Kristeva on Maternity," Signs 18.1 (1992): 111-135. See also Margaret Simmons, "Bergson's Influence on Beauvoir's Philosophical Methodology," in The Cambridge Companion to Simone de Beauvoir, ed. Claudia Card (Cambridge: Cambridge University Press, 2003), 107-128; Moira Gatens, "Beauvoir and Biology: A Second Look," in The Cambridge Companion to Simone de Beauvoir, ed. Claudia Card (Cambridge: Cambridge University Press, 2003), 266-285; Elizabeth Fallaize, "A Saraband of Imagery: The Uses of Biological Science in Le deuxième sexe," in The Existential Phenomenology of Simone de Beauvoir (Springer Netherlands, 2001), 67-84; Anna Mudde, “New Situations: Beauvoir's (Feminist) Philosophy of Science," presented at the 2010 meeting of The International Association of Women Philosophers: Feminism, Science, and Values (Saturday June 26, 2010); and Anna Mudde, "Living Experiments: Beauvoir, Freedom, and Science." PhaenEx 10 (2015): 57-75. 
2 Anna Mudde notes that Beauvoir's influence on feminist philosophy of science and feminist epistemology has been "relatively limited" ("New situations"). This should surprise us because, as Christine Delphy points out, Beauvoir stands out within the "French Feminisms tradition" precisely for not adopting a primarily deconstructive, psychoanalytic, or post-structuralist methodology (as, arguably, Julia Kristeva, Hélène Cixous, and Luce Irigaray all do). She adopts a materialist framework that is much more amenable to the findings of empirical science and that shares certain commonalities with the recent "materialist turn" in feminist theory spearheaded by thinkers such as Isabelle Stengers, Donna Haraway, Jane Bennett, Karen Barad, Rosi Braidotti, and Elizabeth Grosz (Christine Delphy, "The Invention of French Feminism: An Essential Move," French Studies 87 [1995]: 190-221). On the recent surge of materialist philosophy in feminist theory, see Jane Bennett et al., New Materialisms: Ontology, Agency, and Politics, eds. Diana Coole and Samantha Frost (Durham: Duke University Press, 2010).

${ }^{3}$ Beauvoir, Memoirs, 69.

${ }^{4}$ In Memoirs of a Dutiful Daughter, Beauvoir describes herself as a young woman charmed by scientific inquiry and captivated by scientific problems. During her formative years, roughly from 1915 to 1925, she attended a series of private religious schools (the Cours Désir and the Institut (atholique), where she received a rigorous catholic education at her mother's request. This education included training in theology, philosophy, and literature. But it had also a robust scientific component. In "Book One," for example, she talks about her education at the Cours Désir and mentions being fascinated by geography, enchanted by mathematics, and highly passionate about physics (Simone de Beauvoir, Memoirs of a Dutiful Daughter [Kent: World Publishing Company, 1959], 22, 157). For the young Beauvoir, the sciences of life, matter, and number represented exciting fields of research in which a rational bridge could be erected between mind and world. These sciences, with their empirical content and formal methods, gave her a sense of substance or substantiality that she could not find anywhere else in the curriculum-a certain feeling that, upon dwelling in these spaces of human reason, her intellect could touch something real and palpable, something perhaps "absolute." At the Cours Désir, she writes, "I liked things I could get my teeth into, like mathematics."

${ }^{5}$ See Simone de Beauvoir, "Les structures élémentaires de la parentage par Claude Lévi-Strauss," Les temps modernes 5.2 (1949): 943-9; Simone de Beauvoir, "La phénoménologie de la perception de Maurice Merleau-Ponty," Les temps modernes 1.2 (1945): 363-67; and Sara Heinämaa, "Introduction to a Review of The Phenomenology of Perception by Maurice MerleauPonty," in Simone de Beauvoir: Philosophical Writings, ed. Margaret Simons, Marybeth Timmermann, and Mary Beth Mader (Chicago: University of Illinois Press, 2004), 153-8.

${ }^{6}$ Andrew, "Beauvoir's Place in Philosophical Thought," 25.

7 For a theory of the politics of reading, see Michel de Certeau, The Practice Of Everyday Life (Berkeley: University Of California Press, 1984).

8 Margaret Simons and Hélène Peters, "Introduction to Analysis of Claude Bernard's Introduction to the Study of Experimental Medicine," in Simone de Beauvoir: Philosophical Writings, ed. Margaret Simons, Marybeth Timmermann, and Mary Beth Mader (Chicago: University of Illinois Press, 2004), 16.

9 Several commentators have noted that the celebrated chapter on "Biological Data"-the place, if any, where Beauvoir's investment in empirical science shines most resplendently-has not fared too well in the secondary literature. Like most of her other engagements with science, this chapter continues to occupy an at-best marginal position in the Beauvoir studies literature (Gatens, "Beauvoir and Biology," 267). As deplorable as it may sound, the fact is that this 
chapter is more frequently mentioned and cited by scholars than actually read by them. As such, it has become the conspicuous dead spot in the Beauvoir studies literature-"a somewhat unenviable reputation," to quote Elizabeth Fallaize ("A Saraband of Imagery," 67).

10 Barbara Andrew, "Beauvoir's Place in Philosophical Thought," in The Cambridge Companion to Simone de Beauvoir, ed. Claudia Card (Cambridge: Cambridge University Press, 2003), 24-44.

11 Ursula Tidd argues that the reception of Beauvoir's corpus in philosophical milieus has been ambivalent. "Such vicissitudes in its reception have been related to the nature of Beauvoir's philosophical collaboration with Jean-Paul Sartre, the role of women in intellectual history and philosophy more generally, and to the status of Le Deuxième Sexe - the text for which Beauvoir is still best known" (Ursula Tidd, "Simone de Beauvoir Studies," French Studies 62.2 [2008]: 200).

12 Although the term "rational reconstruction" admits of multiple meanings in different theoretical registers, I shall here use the term to describe a procedure whereby the ideas and arguments of a thinker are re-constructed in way that makes the implicit explicit. The present rational reconstruction is meant to enable the reader to identify and bring to the foreground those aspects of Beauvoir's argument in the chapter on biology that are particularly germane to the philosophy of science.

${ }^{13}$ Certainly, "existentialism" is not an internally coherent whole. Neither is it a monolith. It is a loose assortment of philosophical, literary, and social projects that share more or less degrees of similarity (David Cooper, Existentialism: A Reconstruction [Hoboken: Wiley-Blackwell, 1999]).

${ }^{14}$ Deirdre Bair, Simone de Beauvoir: A Biography (New York City: Simon and Schuster, 1991), 391.

15 "Research programs" are sub-sections of scientific domains with relatively well defined research objectives, agendas, and methodologies. Examples may include evolutionary theory, endocrinology, physiology, etc. For a full account, see Imre Lakatos, The Methodology of Scientific Research Programmes (Cambridge: Cambridge University Press, 1980).

16 Simone de Beauvoir, The Second Sex, ed. Constance Borde and Sheila Malovany-Chevallier (New York: Vintage Books, 2011), 22-3.

17 Ibid.

${ }^{18}$ In fn. 7, Beauvoir quotes the following excerpt from Phenomenology of Perception: "I am thus my body, at least inasmuch as I have experience, and reciprocally, my body is like a natural subject, like a tentative draft of my total being" (Ibid., 41).

19 lbid., 24.

20 Beauvoir does not say to whom, specifically, this imaginary position belongs. But Freud is a good candidate. In Beyond the Pleasure Principle, Freud argues that the germ-cells work in the opposite direction of the death drive. They do not push the organism toward death, but they do push the species toward eternity. "These germ-cells, therefore, work against the death of the living substance and succeed in winning for it what we can only regard as potential immortality, though that may mean no more than a lengthening of the road to death. We must regard as in the highest degree significant the fact that this function of the germ-cell is reinforced, or only made possible, if it coalesces with another cell similar to itself and yet different from it" (Sigmund Freud, Beyond the Pleasure Principle [New York: Bantam Books, 1959], 73-4).

${ }^{21}$ Beauvoir, The Second Sex, 21.

22 Parthenogenesis refers to a type of asexual reproduction that occurs without fertilization. 


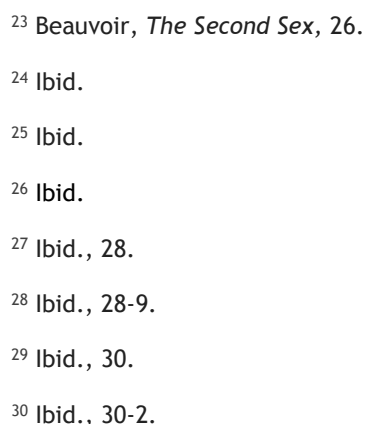

${ }^{30}$ lbid., 30-2.

31 For an account of Beauvoir's thinking about hermaphroditism (and the more recent concept of "intersex"), see Sara Heinämaa, "What Is a Woman? Butler and Beauvoir on the Foundations of the Sexual Difference," Hypatia 12.1 (1997): 20-39.

32 Beauvoir, The Second Sex, 31.

${ }^{33}$ Freud, Beyond the Pleasure Principle, 73.

34 This stage of her argument is, on my view, the most bewildering of them all because it secretes a grandiose philosophy of life redolent of eighteenth century natural history and nineteenth century Lebensphilosophie. Its metaphysical overtones are also striking because they stand in direct tension with Beauvoir's promise (earlier on in the chapter) that she would avoid trafficking in metaphysical principles when thinking about biology, evolution, and life.

35 Beauvoir, The Second Sex, 31.

36 Ibid., 38. Debra Bergoffen claims that Beauvoir's position problematically presupposes that women are, in some sense, enslaved by their biology, "that ovaries and uteri are marks of immanence" (Debra Bergoffen, The Philosophy of Simone de Beauvoir: Gendered Phenomenologies, Erotic Generosities [New York: State University of New York Press, 1997], 151).

37 I believe she gets this dualism from the French philosopher Henri Bergson, who uses a similar metaphysical framework of rupture and continuation ("open" and "close") to make sense of morality and evolutionary theory. See Henri Bergson, The Two Sources of Morality and Religion (Notre Dame, IN: University of Notre Dame Press, 1977 [1935]); and The Creative Mind: An Introduction to Metaphysics (New York: Dover Publications, 1998 [1946]).

${ }^{38}$ Moira Gatens points that there are many places in The Second Sex where deeply essentialist and deeply constructivist statements are side-by-side and "it is not [always] easy to know how to balance the two kinds of statements" ("Beauvoir and Biology," 272). The lebensphilosopie sketched in "Biological Data" is one of these cases, especially in virtue of its assumption that the animal kingdom has a tree-like or ladder-like structure, with some organisms at the base and others at the top. For an analysis of the concept of "tree of life" in biological discourse, see the 2010 special issue of Biology \& Philosophy (Volume 25, Issue 4).

39 Beauvoir, The Second Sex, 44. According to Judith Butler, Beauvoir “distinguishes between natural facts and their significance, and argues that natural facts gain significance only through their subjection to non-natural systems of interpretation." See Judith Butler, "Sex and Gender in Simone de Beauvoir's Second Sex," French Studies 72 (1986): 45. 
${ }^{40}$ Gatens, "Beauvoir and Biology,” 270.

41 Beauvoir discusses the masculine bias of scientific research in a 1976 interview with Susan J. Brison in Rome. See Susan Brison, "Beauvoir and Feminism: interview and reflections," in The Cambridge Companion to Simone de Beauvoir, ed. Claudia Card (Cambridge: Cambridge University Press, 2003), 189-207. In this article but also in many other places, Beauvoir holds that since the biologist's pronouncements "are not immune from masculinist bias" (Ursula Tidd, Simone de Beauvoir [London: Routledge, 2004], 54), biological discourse and biological knowledge must be subjected to rigorous and systematic social critique, which is precisely what The Second Sex purports to deliver.

42 Beauvoir, The Second Sex, 44.

43 Ibid., 41.

${ }^{44}$ I take it this is what is at stake in Debra Bergoffen's plea for a "a phenomenology of the second sex" (The Philosophy of Simone de Beauvoir, 155-8).

${ }^{45}$ Beauvoir, The Second Sex, 44.

${ }^{46} \mathrm{lbid}$.

${ }^{47}$ Ibid.

48 See Rachel Malane, Sex in Mind: The Gendered Brain in Nineteenth-Century Literature and Mental Sciences (New York: Peter Lang, 2005).

${ }^{49}$ Although Beauvoir presents her comments as a critique of physiology, some of the research she describes could easily be classified under various other scientific fields of the late nineteenth and early twentieth centuries, including physical anthropology, craniometry, and anthropometry.

${ }^{50}$ Beauvoir, The Second Sex, 45.

51 Ibid.

${ }^{52}$ A good critique of this way of thinking about intelligence is found in Stephen Jay Gould's The Mismeasure of Man (New York: WW Norton \& Company, 1996). For an example of how the distinction between function and quantity is employed in contemporary debates in the philosophy biology, see Monika Piotrowska, "What Does It Mean to Be 75\% Pumpkin? The Units of Comparative Genomics," Philosophy of Science 76.5 (2009): 838-850.

${ }^{53}$ Beauvoir, The Second Sex, 45.

54 See Bernhard Forchtner, "Jürgen Habermas' Language-philosophy and the Critical Study of Language," Critical approaches to discourse analysis across disciplines 4.1 (2010): 18-37.

55 Figures normally mentioned in discussions of immanent critique include Theodor Adorno, Max Horkheimer, Herbert Marcuse, Erich Fromm, and Jürgen Habermas. In my view, one of the most remarkable displays of this method is Adorno and Horkheimer's diagnosis of capitalism's regressive tendencies in Dialectic of Enlightenment (Palo Alto: Stanford University Press, 2002 [1944]). On the subject of immanent critique, see also Columba Peoples, "Theodor Adorno," in Critical Theorists and International Relations, ed. J. Edkins, and N. Vaughan-Williams (Oxon: Routledge, 2009), 7-10.

56 lbid., 45. 
${ }^{57}$ This view presupposes empirical knowledge that currently does not exist and mistakenly assumes that all the dynamics relevant to the process of reproduction have been observed, registered, and decoded by scientists. In reality, however, there are too many gaps in biology's empirical support base-too many "known unknowns"-that cast a shadow of doubt on the empirical credentials of views like this. At present, Beauvoir says, "the details of the psychochemical interactions leading up to fertilization are not known" (Ibid., 28). And the details of ovulation, too, "are still quite mysterious" (Ibid., 41).

58 The same is true of others concepts that have made their way into biological polemics in the twentieth century, such as the concepts of possibility and subjectivity.

59 Beauvoir notes that the process of sex determination can be changed, and even reversed, by manipulating the endocrinological milieu (Ibid., 30).

60 lbid., 45.

61 "For man: W. $0.56=498,1,360 / 498=2.73$. For woman: W. $0.56=446,1,220 / 446=2.74$ " (Ibid., 50). Beauvoir, unfortunately, does not specify why she divides brain weight by .56 of body weight.

62 Ibid., 42

${ }^{63}$ Consider Fouillée's theory. In developing his theory of reproduction, Fouillée evokes the classical Aristotelian contrast between male activity and female passivity. What is symptomatic about this is not that Fouillée appeals to an Aristotelian philosophy that is pre-scientific. What is symptomatic is that the appeal itself takes place at a historical juncture, the end of the nineteenth century, when there the evidence against this view of reproduction is all but insurmountable. By the late nineteenth century a series of scientific developments (such as the invention of the microscope and the discovery of cell theory) had already made possible the empirical verification of "the symmetry of the two gametes' nuclei" and given biologists all the resources needed to move beyond the historically dominant thesis of gametic inequality. From 1827 to 1883 , in other words, biology made significant leaps in the theory of reproduction-all of which suggested, when objectively analyzed, that the male and female play equal roles in the creation of new life. Why then does Fouillée, writing only ten years after the Edouard Van Beneden's discovery of gametic symmetry in 1883 , cling on to the thesis of gametic inequality? Because this thesis is part and parcel of the ideology of male supremacy that lies at the heart of the West's history and has framed the experiences and expectations of men like Fouillée. If, in 1895, Fouillée can write a work like Tempérament et caractère selon les individus, les sexes et les races and present it as "scientific," this is because the theoretical position therein expressed carries within itself an aura of validity that emanates from the socio-cultural element in which this theory is "embedded." She writes: "Alfred Fouillée claimed he could define woman entirely from the ovum and man from the sperm; many so-called deep theories are based on this game of dubious analogies. It is never clear what philosophy of nature this pseudo-thinking [pseudopensées] refers to. If one considers the laws of heredity, men and women come equally from a sperm and an ovum. I suppose the vestiges of the old medieval philosophy [...] are floating around in these foggy minds; it was imagined that the ovum is a female homunculus and woman a giant ovum. These reveries dismissed since the days of alchemy make a weird contrast with the scientific precision of description being used at this very moment" (Ibid., 29). On this point Beauvoir is quite unequivocal: this is not exact science. It is sloppy ideology. It is patriarchy masquerading as biological inevitability.

${ }^{64}$ Beauvoir, The Second Sex, 44.

65 Ibid., 46. 
${ }^{66}$ Karen Vintges offers an intriguing interpretation of the scientific aspirations of The Second Sex and defends Beauvoir against the accusation that her methodology violates the most basic norms of scientific procedure. See Karen Vintges, "The Second Sex and Philosophy," in Feminist Interpretations of Simone de Beauvoir, ed. Margaret Simons (University Park: Pennsylvania State University, 1995), 45-58.

${ }^{67}$ Gatens, "Beauvoir and Biology," 267.

${ }^{68}$ See Nancy Bauer, “Must We Read Simone de Beauvoir?" in The Legacy of Simone de Beauvoir, ed. by Emily R. Grosholz (Oxford: Clarendon Press, 2004), 115-35.

69 Just consider, for example, the unabashedly anti-existentialist posturing of defenders of "speculative realism," including Quentin Meillassoux and Graham Harman, as well as of various other continentally-trained philosophers of science, such as Michel Serres, Bruno Latour, and even Gilles Deleuze.

70 See Edward Fullbrook and Kate Fullbrook, Simone de Beauvoir: A Critical Introduction (Cambridge: Polity, 1998), 42-6; and Simons and Peter, "Introduction to Analysis of Claude Bernard's Introduction to the Study of Experimental Medicine."

71 In America Day by Day, Beauvoir quotes at length from Gunnar Myrdal's 1944 social-scientific study of race in America. See Gunner Myrdal, An American Dilemma: The Negro Problem and Modern Democracy (Berkeley, California: University of California Press, 2000 [1944]).

72 See the chapter on "The Nomads" from The Second Sex and her 1949 review of Claude LéviStrauss' The Elementary Structures of Kinship.

${ }^{73}$ Simone de Beauvoir, Letters to Sartre (New York: Arcade Publishing, 1993), 124.

${ }^{74}$ Tidd, Simone de Beauvoir, 64; Beauvoir, The Second Sex, 471-2.

75 Simmons, "Bergson's Influence on Beauvoir's Philosophical Methodology."

${ }^{76}$ Beauvoir, The Second Sex, 287n, 292.

${ }^{77}$ Julie Ward, "Beauvoir's Two Senses of 'Body' in The Second Sex," in Feminist Interpretations of Simone de Beauvoir, ed. Margaret Simons (University Park: Pennsylvania State University, 1995), 226.

${ }^{78}$ Kristana Arp goes as far as to claim that the content of the chapter on biology is irrelevant to the question of women's phenomenological experience of reality. She says: "I contend that we should acknowledge the power of Beauvoir's analysis here while mainly discounting her remarks on female biology." See Kristana Arp, "Beauvoir's Concept of Bodily Alienation," in Feminist Interpretations of Simone de Beauvoir, ed. Margaret Simons (University Park: Pennsylvania State University, 1995), 162. 